\title{
The Ethos of Romance at the Turn of the Century
}


THIS PAGE INTENTIONALLY LEFT BLANK 


\section{The Ethos of Romance at the Turn of the Century William F. Scheick}

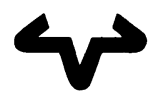

University of Texas Press Austin 
Copyright $\mathbb{C} 1994$ by the University of Texas Press

All rights reserved

First edition, 1994

Requests for permission to reproduce material from this work should be sent to

Permissions

University of Texas Press

Box 7819

Austin, TX 78713-7819.

Grateful acknowledgment is made for permission to reprint material previously published in ESQ: A Journal of the American Renaissance 24 (1978): 72-76; English Literature in Transition 34 (1991): 19-20; Studies in Scottish Literature 27 (1992): I-6; and The Cunning Craft: Original Essays on Detective Fiction and Contemporary Literary Theory, ed. Ronald G. Walker and June M. Frazer (Macomb: Western Illinois University, 1990), pp. 86-97.

@ The paper used in this publication meets the minimum requirements of American $\mathrm{Na}$ tional Standard for Information Sciences-Permanence of Paper for Printed Library Materials, ANSI Z39.48-I984.

Library of Congress Cataloging-in-Publication Data

Scheick, William J.

The ethos of romance at the turn of the century / William J. Scheick. - ist ed.

p. $\quad \mathrm{cm}$.

Includes bibliographical references (p.) and index.

ISBN 0-292-77673-X

I. English fiction-19th century-History and criticism. 2. Romances-

Adaptations-History and criticism. 3. Popular literature-Great Britain-History and criticism. 4. Popular literature-United States-History and criticism.

5. American fiction-19th century-History and criticism. 6. Ethics in literature.

7. Narration (Rhetoric) 8. Fiction-Technique. I. Title.

PR878.R7S34 1994

$823^{\prime} .0850908$ - dc2o 
For Gatherine and for Yessica and Nathan 
THIS PAGE INTENTIONALLY LEFT BLANK 